Cite this: RSC Adv., 2014, 4, 62728

Received 13th October 2014 Accepted 11th November 2014

DOI: $10.1039 / c 4 r a 12284 d$

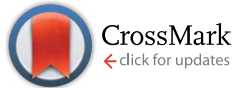

www.rsc.org/advances

\section{Influence of a co-adsorbent on the performance of bis(diimine) copper(,)-based dye-sensitized solar cells $\dagger$}

\author{
Sven Y. Brauchli, Frederik J. Malzner, Edwin C. Constable* \\ and Catherine E. Housecroft*
}

In the bis(diimine) copper(I) dyes, $[\mathrm{Cu}(1)(3)]^{+}$and $[\mathrm{Cu}(1)(4)]^{+}\left(1=\left(\left(6,6^{\prime}\right.\right.\right.$-dimethyl-[2,2'-bipyridine $]-4,4^{\prime}$-diyl)bis(4,1-phenylene))bis(phosphonic acid), the ancillary ligands 3 and 4 contain sterically demanding secondgeneration hole-transporting dendrons with methyl or phenyl substituents adjacent to the $\mathrm{N}$-donor atoms of the 2,2'-bipyridine metal-binding domain. The performances of DSCs containing $[\mathrm{Cu}(1)(3)]^{+}$and $[\mathrm{Cu}(1)(4)]^{+}$depend on both the solvent (acetone or $\mathrm{CH}_{2} \mathrm{Cl}_{2}$ ) used in the dye-bath and on the presence of a co-adsorbent. Irrespective of solvent, the dye $[\mathrm{Cu}(1)(4)]^{+}\left(6,6^{\prime}-\mathrm{Ph}_{2}\right.$-substituted) only performs well if chenodeoxycholic acid (cheno) is added as a co-adsorbent; for [Cu(1)(3)] ${ }^{+}$, cheno has a noticeable effect when the dye assembly is carried out in $\mathrm{CH}_{2} \mathrm{Cl}_{2}$. Overall, the results indicate that a combination of small $6,6^{\prime}$-substituents in the ancillary ligand and acetone in the dye-dipping cycle lead to the best performing dyes, and for the second-generation dyes, the addition of cheno is essential. Conditions to form $\mathrm{TiO}_{2}{ }^{-}$ bound $[\mathrm{Cu}(1)(5)]^{+}\left(5=4,4^{\prime}\right.$-bis(4-iodophenyl)-6,6'-dimethyl-2, $2^{\prime}$-bipyridine) in a stepwise manner have been optimized and the effects of introducing cheno at different points during the dye-assembly process have been investigated. When cheno is added to the $\left[\mathrm{Cu}(\mathrm{MeCN})_{4}\right]\left[\mathrm{PF}_{6}\right] / 5$ dye-bath, the DSCs exhibit values of $J_{S C}, V_{O C}$ and $\eta$ values that are similar to those with no co-adsorbent. However, competitive binding of 1 and cheno in the first dipping-cycle leads to lower values of $J_{S C}$ and lower photoconversion efficiencies.

\section{Introduction}

Dye-sensitized solar cells (DSCs) with bis(diimine) copper(I) complexes $^{1}$ as sensitizers have recently been reported with photoconversion efficiencies (PCE) exceeding 3\%., ${ }^{2,3}$ Several approaches have been adopted for the anchoring of copper(I) dyes to the nanoparticulate $\mathrm{TiO}_{2}$ semiconductor surface. Initial studies focused on the use of homoleptic $\left[\mathrm{CuL}_{2}\right]^{+}$complexes as dyes with anchoring domains in both ligands. ${ }^{4-9}$ An improved method of dye assembly utilizes the lability of bis(diimine) copper(I) complexes and permits stepwise assembly of surfacebound heteroleptic dyes. The metal oxide is first treated with an anchoring ligand such as the bis(phosphonic acid) $\mathbf{1}^{\mathbf{1 0}}$ (Scheme 1), and the functionalized material is then soaked in a solution containing a homoleptic complex $\left[\mathrm{Cu}\left(\mathrm{L}_{\text {ancillary }}\right)_{2}\right]^{+}$. Equilibration to generate the surface-bound heteroleptic

Department of Chemistry, University of Basel, Spitalstrasse 51, CH4056 Basel, Switzerland.E-mail: edwin.constable@unibas.ch; catherine.housecroft@unibas.ch; Tel: +41-61-267-1008

$\dagger$ Electronic supplementary information (ESI) available: Tables S1-S3: complete sets of DSC parameters including duplicate cells; Fig. S1 solid-state absorption spectra of electrodes with dyes $[\mathrm{Cu}(\mathbf{1})(\mathbf{3})]^{+}$and $[\mathrm{Cu}(\mathbf{1})(\mathbf{4})]^{+}$. See DOI: $10.1039 / \mathrm{c} 4 \mathrm{ra} 12284 \mathrm{~d}$ complex $\left\{\mathrm{Cu}(\mathbf{1})\left(\mathrm{L}_{\text {ancillary }}\right)\right\}$ is rapid, and the strategy permits effective screening of a wide range of dyes comprising different anchoring and ancillary diimine ligands. ${ }^{2,10-16}$ To optimize atom efficiency, surface-bound heteroleptic dyes can also be assembled by treating the anchor-functionalized $\mathrm{TiO}_{2}$ surface with a performance of these cells is comparable to those of cells comprising the corresponding dye made by the on-surface ligand exchange procedure.

The isolation of heteroleptic bis(diimine) copper(I) complexes is usually difficult because of rapid equilibration between homo- and heteroleptic species in solution. ${ }^{17}$ One way to overcome this is the HETPHEN approach ${ }^{18}$ which employs

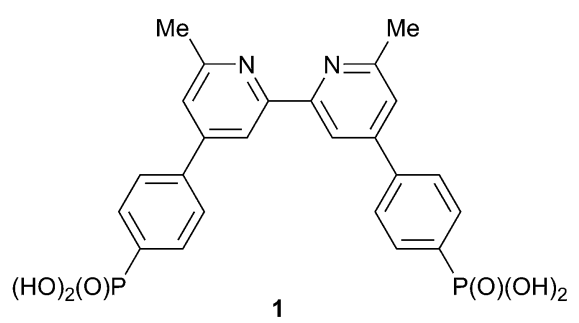

Scheme 1 Structure of anchoring ligand 1. $1: 1$ mixture of $\left[\mathrm{Cu}(\mathrm{MeCN})_{4}\right]^{+}$and the ancillary ligand. ${ }^{2}$ The DSC 
sterically demanding substituents adjacent to the N-donors in one diimine ligand.,19 Using this strategy, a record PCE of $4.66 \%$ has been reached with the $\left[\mathrm{Cu}\left(\mathrm{L}_{\text {anchor }}\right)\left(\mathrm{L}_{\text {ancillary }}\right)\right]^{+}$dye in which $\mathrm{L}_{\text {anchor }}$ is $6,6^{\prime}$-dimesityl-2,2'-bipyridine-4,4'-dicarboxylic acid and $\mathrm{L}_{\text {ancillary }}$ is a $2,2^{\prime}$-bipyridine ancillary ligand bearing peripheral triphenylamino domains. The use of the coadsorbant chenodeoxycholic acid (cheno, Scheme 2) is critical to the attainment of this high PCE. ${ }^{3}$ Surprisingly few studies have probed the effects of co-adsorbants on copper(I) dyes, although it is well known that cheno enhances the open-circuit voltage $\left(V_{\text {OC }}\right)$ of ruthenium(II)-containing dyes such as N719, ${ }^{20}$ and zinc(II) porphyrin dyes..$^{\mathbf{2 1 , 2 2}}$ We have reported that the addition of cheno to the homoleptic dyes shown in Scheme $3 \mathrm{a}$ does not enhance the PCE, ${ }^{6}$ whereas Robertson and coworkers report improved photocurrents when cheno is added to the sensitizer $\left[\mathrm{Cu}\left(4,4^{\prime}-\left(\mathrm{HO}_{2} \mathrm{C}\right)_{2} \mathrm{bpy}\right)(\mathrm{POP})\right]^{+}$(Scheme $\left.3 \mathrm{~b}\right) .^{23}$

The reduction in dye loading resulting from the presence of co-adsorbants should counter the ripening effects that DSCs

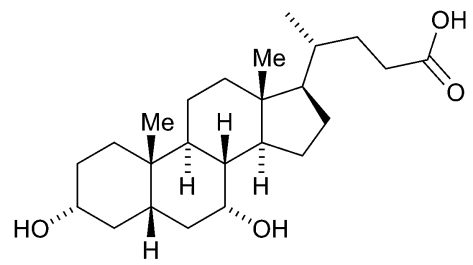

Scheme 2 Structure of co-adsorbant chenodeoxycholic acid (cheno).

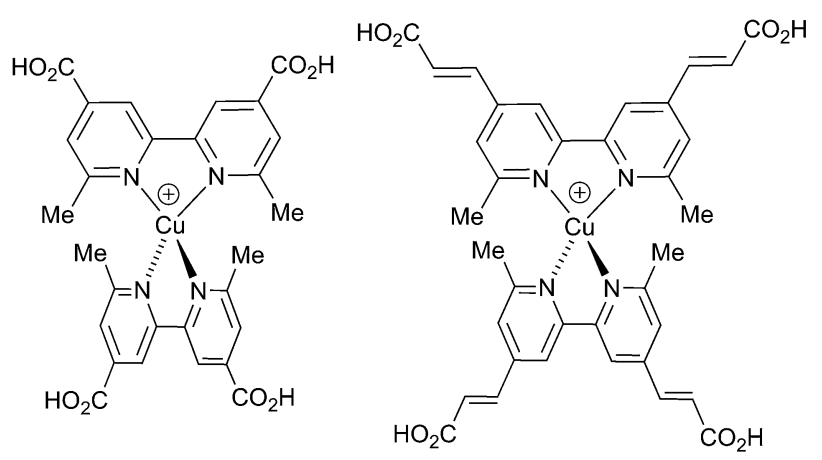

(a)

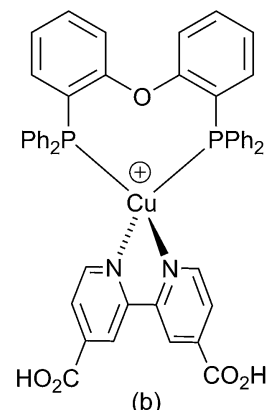

(b)

Scheme 3 (a) Two bis(diimine) copper(I) dyes for which the addition of cheno has no effect on DSC performance, ${ }^{6}$ and (b) the dye $\left[\mathrm{Cu}\left(4,4^{\prime}-\right.\right.$ $\left(\mathrm{HO}_{2} \mathrm{C}\right)_{2}$ bpy) (POP) $]^{+}$for which addition of cheno results in improved short-circuit current. ${ }^{23}$ utilizing copper(I)-containing dyes experience with an $\mathrm{I}^{-} / \mathrm{I}_{3}{ }^{-}$

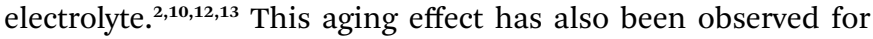
ruthenium(II) dyes and is explained in terms of disaggregation and reorganization of the sensitizer molecules on the $\mathrm{TiO}_{2}$ surface. ${ }^{24-26}$ On the other hand, we have also noted that if the ancillary ligand is small (e.g. 6,6'-dimethyl-2,2'-bipyridine, dmbpy), optimum PCE is achieved on the day of DSC fabrication, indicating that molecular dyes such as $[\mathrm{Cu}(\mathbf{1})(\mathrm{dmbpy})]^{+}$ undergo little or no time-dependent reorganization on the surface. ${ }^{27}$ Controlled dye loading is critical to achieving optimal DSC performance immediately after DSC fabrication as shown by varying the concentration of the homoleptic $\left[\mathrm{Cu}\left(\mathrm{L}_{\text {ancillary }}\right)_{2}\right]^{+}$ during the soaking step in the stepwise assembly of $\left[\mathrm{Cu}\left(\mathrm{L}_{\text {anchor }}\right)\left(\mathrm{L}_{\text {ancillary }}\right)\right]^{+}$on a $\mathrm{TiO}_{2}$ surface. ${ }^{28}$ In this latter investigation, $\mathrm{L}_{\text {anchor }}$ was phosphonic acid $\mathbf{1}$ and the ancillary ligand was the first-generation dendron 2 (Scheme 4).

Here we report a study of the effects on DSC performance of combining cheno with three dyes. The latter were selected because, for copper(I) containing dyes, they give moderate to good photoconversion efficiencies., ${ }^{2,16}$ The first two dyes, $[\mathrm{Cu}(\mathbf{1})(\mathbf{3})]^{+}$and $[\mathrm{Cu}(\mathbf{1})(\mathbf{4})]^{+}$, contain sterically demanding second-generation hole-transporting dendrons (Scheme 4) while the third dye, $[\mathrm{Cu}(\mathbf{1})(\mathbf{5})]^{+}$, contains the iodo-functionalized bpy ligand 5 (Scheme 4). All three dyes have been the subject of recent studies, and all show ripening effects. ${ }^{2,16}$ We also optimize the conditions for the stepwise, atom efficient assembly of surface-bound $[\mathrm{Cu}(\mathbf{1})(\mathbf{5})]^{+}$.

\section{Experimental}

\section{Ligands and complexes}

Ligands $\mathbf{1}^{10} \mathbf{3}^{16} \mathbf{4}^{\mathbf{1 6}}$ and $\mathbf{5}^{\mathbf{2}}$ were prepared as previously described. $\left[\mathrm{Cu}(\mathrm{MeCN})_{4}\right]\left[\mathrm{PF}_{6}\right]$ was synthesized by the method of Kubas. ${ }^{29}$

\section{DSC fabrication and measurements}

DSCs were made by adapting a method described by Grätzel and coworkers. $^{\mathbf{3 0 , 3 1}}$ For the photoelectrode, Solaronix Test Cell Titania Electrodes were used. The electrodes were washed with EtOH and sintered at $450^{\circ} \mathrm{C}$ for $30 \mathrm{~min}$, then cooled to $\approx 80{ }^{\circ} \mathrm{C}$ and immersed in a $1 \mathrm{mM}$ DMSO solution of 1 for $24 \mathrm{~h}$, or in a mixture of 1 ( $0.1 \mathrm{mM})$ with cheno in molar ratios $(1: 1,1: 3$ and $1: 6)$ in DMSO for $24 \mathrm{~h}$. The electrode was removed from the solution, washed with DMSO and EtOH and dried with a heat gun at $\approx 60{ }^{\circ} \mathrm{C}$. For dyes containing 3 or 4 , the functionalized electrode was placed in either a $0.1 \mathrm{mM} \mathrm{CH}_{2} \mathrm{Cl}_{2}$ or a $0.1 \mathrm{mM}$ acetone solution of $\left[\mathrm{Cu}(3)_{2}\right]\left[\mathrm{PF}_{6}\right]$ or $\left[\mathrm{Cu}(4)_{2}\right]\left[\mathrm{PF}_{6}\right]$ for 3 days. For dyes containing $\mathbf{5}$, the electrode with adsorbed 1 was immersed in a $0.1 \mathrm{mM} \mathrm{CH}_{2} \mathrm{Cl}_{2}$ solution of a mixture of $5,\left[\mathrm{Cu}(\mathrm{MeCN})_{4}\right]\left[\mathrm{PF}_{6}\right]$ and cheno $(1: 1: 0,1: 1: 1,1: 1: 3,1: 1: 6$ and $1: 1: 10)$ for 1 or 3 days, respectively.

Each reference electrode was prepared by soaking a commercial electrode in a $0.3 \mathrm{mM}$ EtOH solution of dye N719 (Solaronix) for 3 days. After soaking in the dye-baths, the electrodes were removed, washed with the same solvent as used in the dye-bath and dried with a heat gun $\left(\approx 60{ }^{\circ} \mathrm{C}\right)$. 


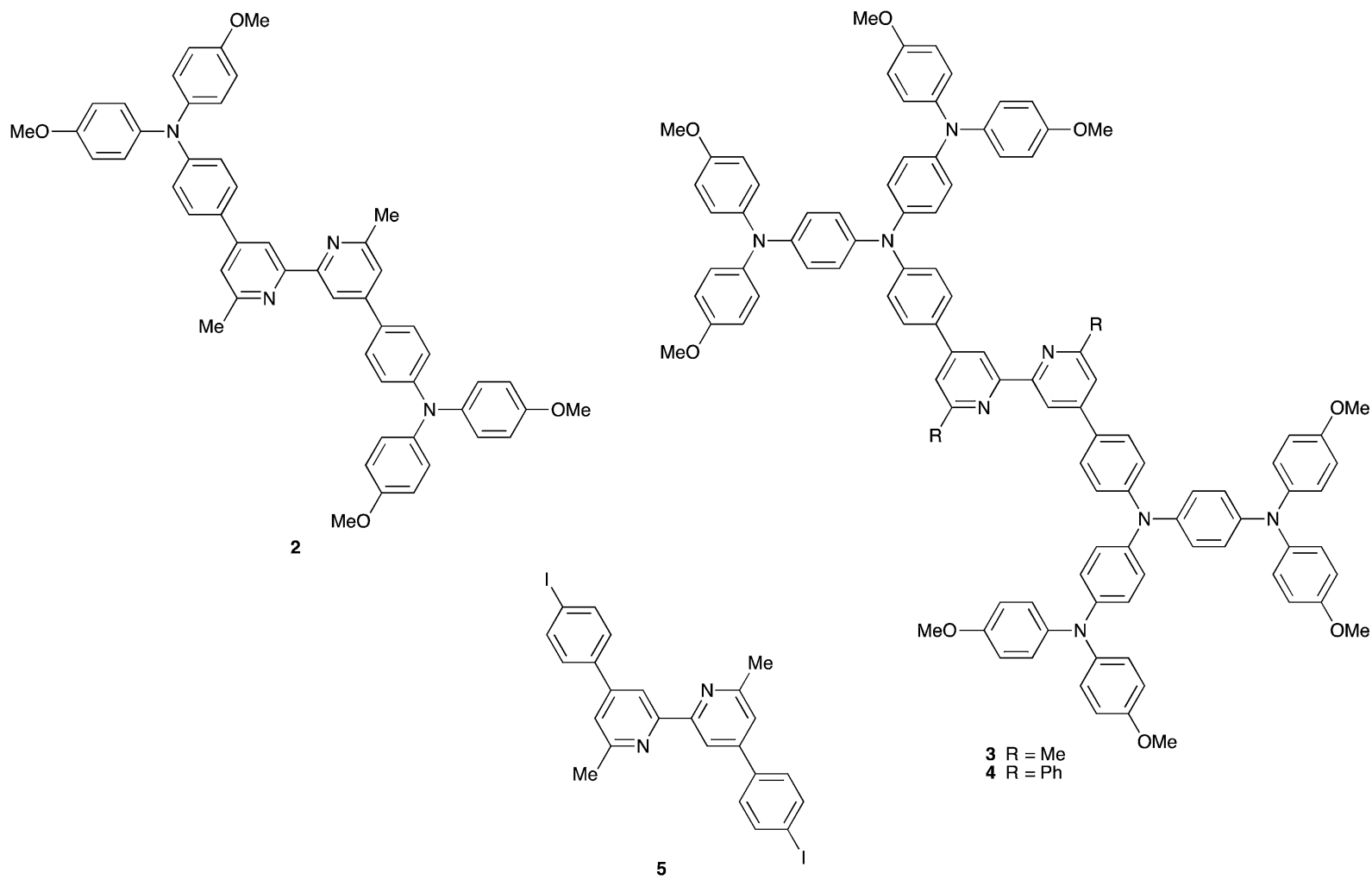

Scheme 4 Structures of the first and second-generation dendritic bpy ligands $2-4$, and of the iodo-derivative 5 .

For the counter electrode Solaronix Test Cell Platinum Electrodes were used, and organic impurities were removed by heating on a heating plate at $450{ }^{\circ} \mathrm{C}$ for $30 \mathrm{~min}$.

The dye-covered $\mathrm{TiO}_{2}$ electrode and $\mathrm{Pt}$ counter-electrode were combined using thermoplast hot-melt sealing foil (Solaronix Test Cell Gaskets) by heating while pressing them together. The electrolyte comprised LiI (0.1 M), I $(0.05 \mathrm{M})$, 1-methylbenzimidazole $(0.5 \mathrm{M})$ and 1-butyl-3-methylimidazolinium iodide $(0.6 \mathrm{M})$ in 3-methoxypropionitrile and was introduced into the DSC by vacuum backfilling. The hole in the counter electrode was sealed using hot-melt sealing foil (Solaronix Test Cell Sealings) and a cover glass (Solaronix Test Cell Caps).

Measurements were made by irradiating from behind using a light source SolarSim $150\left(100 \mathrm{~mW} \mathrm{~cm}^{-2}=1 \mathrm{sun}\right)$. The power of the simulated light was calibrated using a reference Si cell. All DSCs were completely masked ${ }^{32}$ before measurements were made.

\section{External quantum efficiencies}

The external quantum efficiency (EQE) measurements were made using a Spe-Quest quantum efficiency instrument from Rera Systems (Netherlands) with a $100 \mathrm{~W}$ halogen lamp (QTH) and a lambda 300 grating monochromator (Lot Oriel). The monochromatic light was modulated to $3 \mathrm{~Hz}$ using a chopper wheel (ThorLabs). The cell response was amplified with a large dynamic range IV converter (CVI Melles Griot) and measured with a SR830 DSP Lock-In amplifier (Stanford Research).

\section{Results and discussion}

\section{Co-adsorbant cheno with sterically demanding dyes $[\mathrm{Cu}(1)(3)]^{+}$and $[\mathrm{Cu}(1)(4)]^{+}$}

We have previously reported that extending the holetransporting dendron in ancillary ligand 2 to give 3 leads to inferior performances of the second-generation dye $[\mathrm{Cu}(\mathbf{1})(\mathbf{3})]^{+}$ compared to first-generation $[\mathrm{Cu}(\mathbf{1})(2)]^{+} \cdot{ }^{\mathbf{1 6}}$ We were interested in seeing whether the performance of DSCs incorporating the very sterically hindered second-generation ancillary ligand could be improved by adding cheno. Ancillary ligands $\mathbf{3}$ and $\mathbf{4}$ both contain second-generation dendrons, but differ in having methyl or phenyl substituents in the $6,6^{\prime}$-positions, respectively. All data reported for cells without cheno were obtained in a parallel study, where we showed that a combination of small $6,6^{\prime}$-substituents and acetone in the dye-dipping cycle yielded the best performing dendron-containing dyes. ${ }^{16}$ The solvent used in the dye bath is known to influence the efficiency of DSCs, ${ }^{16,33}$ and in the present study, we have used different solvents (acetone and $\mathrm{CH}_{2} \mathrm{Cl}_{2}$ ) in the copper(I) dye baths.

Dye-functionalized photoanodes were made by soaking electrodes in a solution of anchoring ligand $\mathbf{1}$ followed by a dipping cycle in $\mathrm{CH}_{2} \mathrm{Cl}_{2}$ or acetone solutions containing a $1: 1$ mixture of equimolar amounts of cheno and either $\left[\mathrm{Cu}(3)_{2}\right]\left[\mathrm{PF}_{6}\right]$ or $\left[\mathrm{Cu}(4)_{2}\right]\left[\mathrm{PF}_{6}\right]$ (see Experimental section for details). Duplicate DSCs were made for all dye/cheno/solvent combinations and a complete set of performance data is given in Table S1. $\dagger$ Representative data are summarized in Table 1 . Solid state absorption 
Table 1 DSC performance data for masked cells using the dyes $[\mathrm{Cu}(1)(3)]^{+}$and $[\mathrm{Cu}(1)(4)]^{+}$. Relative efficiencies (last column) are with respect to $100 \%$ for the ruthenium(॥) dye N719 measured under the same conditions. See also Table S1. $J_{\text {SC }}=$ short-circuit current density; $V_{\text {OC }}=$ opencircuit voltage; ff = fill factor; $\eta=$ efficiency

\begin{tabular}{|c|c|c|c|c|c|c|c|}
\hline Anchored dye & $\begin{array}{l}\text { Solvent in dye } \\
\text { dipping cycle }\end{array}$ & Co-adsorbant & $J_{\mathrm{SC}} / \mathrm{mA} \mathrm{cm}^{-2}$ & $V_{\mathrm{OC}} / \mathrm{mV}$ & $\mathrm{ff} / \%$ & $\eta / \%$ & Relative $\eta / \%$ \\
\hline \multicolumn{8}{|c|}{ On the day of sealing the cells } \\
\hline$[\mathrm{Cu}(\mathbf{1})(3)]^{+}$ & $\mathrm{CH}_{2} \mathrm{Cl}_{2}$ & Cheno & 6.02 & 531 & 69.6 & 2.23 & 28.0 \\
\hline$[\mathrm{Cu}(\mathbf{1})(3)]^{+}$ & Acetone & - & 6.46 & 515 & 67.9 & 2.26 & $32.8^{a}$ \\
\hline$[\mathrm{Cu}(\mathbf{1})(3)]^{+}$ & Acetone & Cheno & 6.72 & 520 & 60.9 & 2.13 & 26.8 \\
\hline$[\mathrm{Cu}(\mathbf{1})(\mathbf{4})]^{+}$ & Acetone & - & 4.01 & 459 & 70.2 & 1.29 & $18.7^{a}$ \\
\hline$[\mathrm{Cu}(\mathbf{1})(\mathbf{4})]^{+}$ & Acetone & Cheno & 6.34 & 546 & 70.8 & 2.45 & 30.8 \\
\hline N719 & Ethanol & - & 16.73 & 669 & 71.2 & 7.96 & 100.0 \\
\hline \multicolumn{8}{|c|}{22 days after sealing the cells } \\
\hline$[\mathrm{Cu}(\mathbf{1})(\mathbf{3})]^{+}$ & $\mathrm{CH}_{2} \mathrm{Cl}_{2}$ & - & 5.17 & 561 & 69.4 & 2.01 & $25.3^{a}$ \\
\hline$[\mathrm{Cu}(\mathbf{1})(\mathbf{4})]^{+}$ & $\mathrm{CH}_{2} \mathrm{Cl}_{2}$ & Cheno & 4.95 & 555 & 68.3 & 1.87 & 22.7 \\
\hline$[\mathrm{Cu}(\mathbf{1})(\mathbf{4})]^{+}$ & Acetone & - & 4.99 & 487 & 71.3 & 1.73 & $21.3^{a}$ \\
\hline$[\mathrm{Cu}(\mathbf{1})(\mathbf{4})]^{+}$ & Acetone & Cheno & 6.33 & 552 & 70.9 & 2.48 & 30.2 \\
\hline N719 & Ethanol & - & 16.34 & 704 & 71.4 & 8.22 & 100.0 \\
\hline
\end{tabular}

spectra of electrodes (without scattering layer) functionalized with $[\mathrm{Cu}(\mathbf{1})(\mathbf{3})]^{+}$and $[\mathrm{Cu}(\mathbf{1})(\mathbf{4})]^{+}$are shown in Fig. S1, $\dagger$ and demonstrate an enhanced absorption when cheno is present. The addition of cheno improves the performance of dyes $[\mathrm{Cu}(\mathbf{1})(3)]^{+}$and $[\mathrm{Cu}(\mathbf{1})(\mathbf{4})]^{+}$originating from the $\mathrm{CH}_{2} \mathrm{Cl}_{2}$ solutions in the dye baths. The data for the day on which the DSCs were fabricated without and with cheno confirm a significant increase in both the short-circuit current density $\left(J_{\mathrm{SC}}\right)$ and opencircuit voltage $\left(V_{\mathrm{OC}}\right)$. Addition of cheno significantly enhances the performance of $[\mathrm{Cu}(\mathbf{1})(\mathbf{4})]^{+}$when acetone is the solvent for the dye dipping cycle. The efficiency increases from 1.29 to $2.45 \%$ on adding cheno Table 1$)$. In contrast, the improvement in $J_{\mathrm{SC}}$ and $V_{\mathrm{OC}}$ for $[\mathrm{Cu}(\mathbf{1})(\mathbf{3})]^{+}$is small when the dye soaking-cycle involves acetone.

We have previously observed that (in the absence of cheno), a ripening effect is observed for $\mathrm{CH}_{2} \mathrm{Cl}_{2}$-fabricated dyes. ${ }^{16}$ The data in Table 1 show that this time-dependent improvement in efficiency is less $\left(\eta\right.$ increases for $[\mathrm{Cu}(\mathbf{1})(3)]^{+}$from 1.49 to $2.01 \%$ over 22 days) than that produced on the first day by the addition of cheno $(\eta=2.23 \%)$; a small ripening effect is observed when cheno is present $\left(\eta\right.$ increases for $[\mathrm{Cu}(\mathbf{1})(3)]^{+}$from to $2.23-2.47 \%$ over 22 days).

The ancillary ligand in $[\mathrm{Cu}(\mathbf{1})(4)]^{+}$possesses a $6,6^{\prime}-\mathrm{Ph}_{2}$ bpy core (Scheme 4), and the presence of the co-adsorbant has a dramatic effect. The $J-V$ curves shown in Fig. 1 illustrate that the addition of cheno is important for immediately optimizing the DSC performance of the second-generation dye $[\mathrm{Cu}(\mathbf{1})(\mathbf{4})]^{+}$ derived from the acetone dye-soaking cycle (grey versus blue $J-V$ curves in Fig. 1). Most importantly, the enhanced values of short-circuit current density and open-circuit voltage which result from the addition of cheno are maintained over a 3 week period (Fig. 1).

The EQE spectra shown in Fig. 2 for DSCs containing $[\mathrm{Cu}(\mathbf{1})(\mathbf{4})]^{+}$summarize the combined effects of solvent used in the dye bath and cheno additive. The maximum EQE of $49.1 \%$ $\left(\lambda_{\max }=470 \mathrm{~nm}\right)$ after 3 weeks is essentially the same as on the day of sealing the cell $\left(48.3 \%\right.$ at $\left.\lambda_{\max }=480 \mathrm{~nm}\right)$ for acetonederived dyes with cheno. This compares to only $18.0 \%$ rising to $21.3 \%\left(\lambda_{\max }=480 \mathrm{~nm}\right)$ for $[\mathrm{Cu}(\mathbf{1})(\mathbf{4})]^{+} / \mathrm{CH}_{2} \mathrm{Cl}_{2}$ with no coadsorbant. Of note is that the $[\mathrm{Cu}(\mathbf{1})(\mathbf{4})]^{+} /$acetone/cheno combination shows improved electron injection to lower energy (blue curves, Fig. 2).

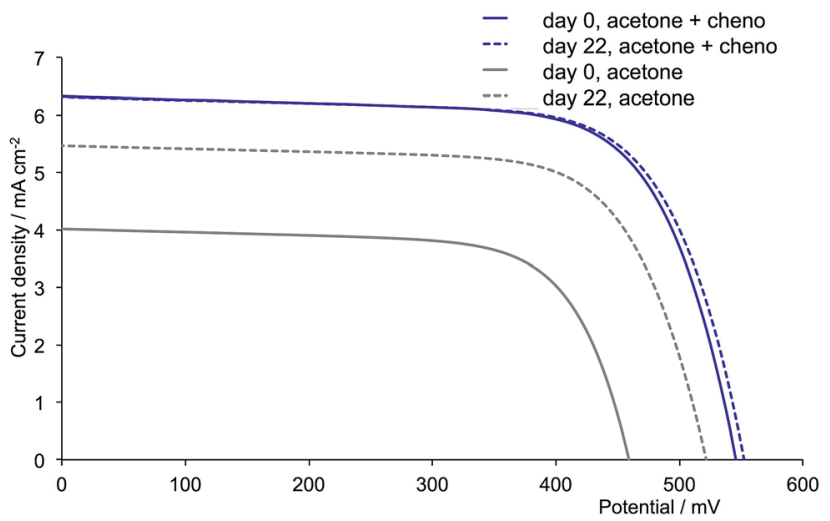

Fig. $1 \mathrm{~J}-V$ curves for DSCs with $[\mathrm{Cu}(1)(4)]^{+}$(acetone used in the $\left[\mathrm{Cu}(4)_{2}\right]\left[\mathrm{PF}_{6}\right]$ dipping cycle) on the day of sealing the DSC (day 0 ) and after 22 days, with (blue curves) and without (grey curves) co-adsorbant cheno. 


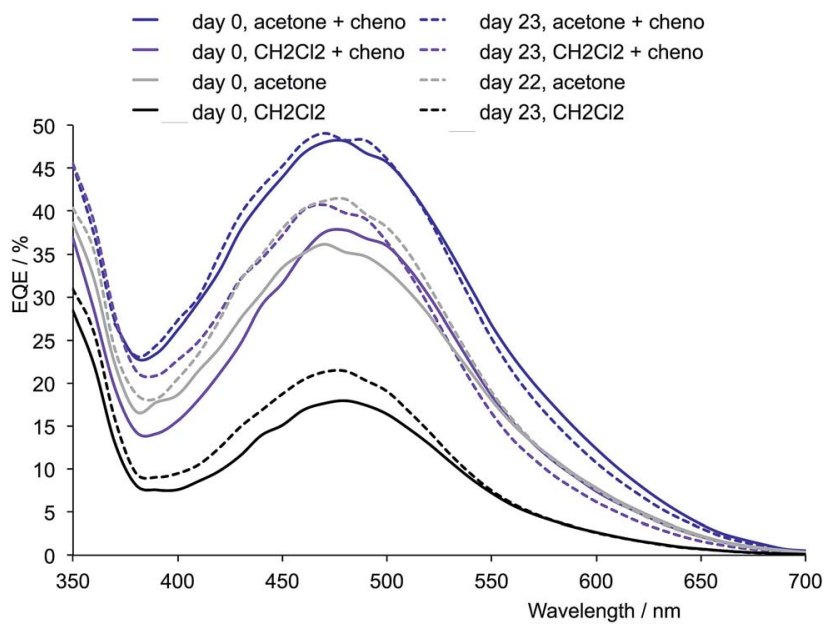

Fig. 2 Dependence of EQE spectra for DSCs with [Cu(1)(4)] ${ }^{+}$(secondgeneration with phenyl substituents) on the solvent used in the $\left[\mathrm{Cu}(4)_{2}\right]$ $\left[\mathrm{PF}_{6}\right]$ dye-soaking cycle, and on the use of co-adsorbant cheno.

Optimizing the procedure for surface assembly of the dye $[\mathrm{Cu}(1)(5)]^{+}$

Recently, we described the effects of different halo-substituents on the performance of DSCs containing the dyes $\left[\mathrm{Cu}(\mathbf{1})\left(\mathrm{L}_{\text {ancillary }}\right)\right]^{+}$where $\mathrm{L}_{\text {ancillary }}$ is $4,4^{\prime}$-bis(4-halophenyl)-6,6'dimethyl-2,2'-bipyridine. The highest efficiency observed was $3.16 \%$ for the dye $[\mathrm{Cu}(\mathbf{1})(5)]^{+}$in which 5 is $4,4^{\prime}$-bis(4-iodophenyl)-6,6'-dimethyl-2,2'-bipyridine (Scheme 4$){ }^{2}$ Comparable efficiencies were obtained when the surface-bound dye was generated by treating $\mathrm{TiO}_{2} / \mathbf{1}$ either with $\left[\mathrm{Cu}(5)_{2}\right]^{+} /$ $\left[\mathrm{Cu}(5)(\mathrm{MeCN})_{2}\right]^{+}$or with a $1: 1$ mixture of $\left[\mathrm{Cu}(\mathrm{MeCN})_{4}\right]^{+}$and $5^{2}$ Compared to dye assembly using the exchange reaction shown in eqn (1), the stepwise method has the advantage of atom efficiency (eqn (2)).

$$
\mathrm{TiO}_{2} / \mathbf{1}+\left[\mathrm{Cu}(\mathbf{5})_{2}\right]^{+} \rightarrow \mathrm{TiO}_{2} /[\mathrm{Cu}(\mathbf{1})(\mathbf{5})]^{+}+\mathbf{5}
$$

$\mathrm{TiO}_{2} / \mathbf{1}+\left[\mathrm{Cu}(\mathrm{MeCN})_{4}\right]^{+}+\mathbf{5} \rightarrow \mathrm{TiO}_{2} /[\mathrm{Cu}(\mathbf{1})(\mathbf{5})]^{+}+4 \mathrm{MeCN}$

The typical soaking time of an anchoring ligandfunctionalized electrode in a solution of a homoleptic complex (eqn (1)) is 3 days. ${ }^{2,10-16}$ However, we argued that a shorter dipping cycle might be sufficient with the stepwise method shown in eqn (2). Table 2 summarizes the results of experiments in which DSCs were assembled by first functionalizing the $\mathrm{TiO}_{2}$-coated electrode with anchoring ligand 1, and then immersing the electrode in a $\mathrm{CH}_{2} \mathrm{Cl}_{2}$ solution containing a mixture of $\left[\mathrm{Cu}(\mathrm{MeCN})_{4}\right]\left[\mathrm{PF}_{6}\right]$ and 5 (each $0.1 \mathrm{mM}$ ) for either 1 or 3 days. Duplicate cells were also tested and showed the same trend as observed in Table 2. A longer dipping time results in improved $J_{\mathrm{SC}}$ and slightly enhanced $V_{\mathrm{OC}}$, leading to a greater overall conversion efficiency. The results also indicate that the efficiency, $\eta$, increases as the DSC matures when a short dyebath cycle is used; this is not the case for the longer dipping time (Table 1). Fig. 3 shows the external quantum efficiency (EQE) spectra for the 7 day old DSCs with EQE maxima of $47.8 \%$ $\left(\lambda_{\max }=480 \mathrm{~nm}, 1\right.$ day in the dye-bath $)$ and $44.7 \%\left(\lambda_{\max }=470 \mathrm{~nm}\right.$, 3 days in the dye bath). The increased spectral response at both

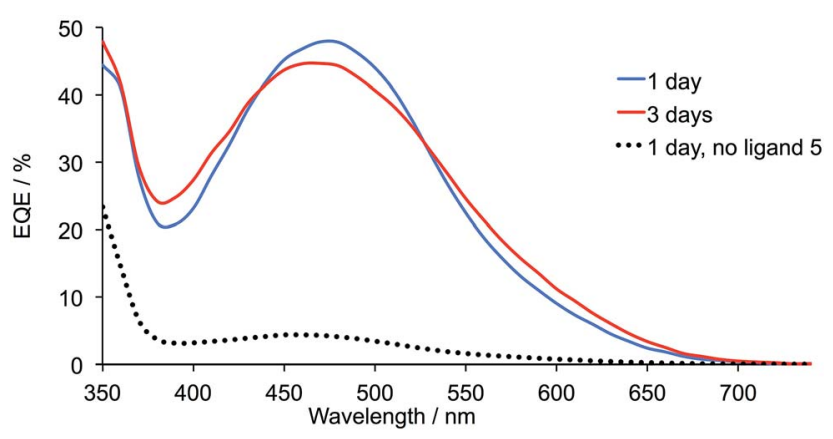

Fig. 3 Comparison of the EQE spectra of 7 day old DSCs with $[\mathrm{Cu}(1)(5)]^{+}$dye assembled by stepwise assembly with a final dippingcycle of 1 or 3 days (blue and red curves). The dotted line represents the EQE spectrum of a DSC made without addition of ligand 5 to the dye (see text).

Table 2 Performance data for masked DSCs with $[\mathrm{Cu}(1)(5)]^{+}$dye; data are compared to a DSC containing N719 and measured under the same conditions

\begin{tabular}{|c|c|c|c|c|c|}
\hline Dye & $\begin{array}{l}\text { Dipping time in } 1: 1\left[\mathrm{Cu}(\mathrm{MeCN})_{4}\right]\left[\mathrm{PF}_{6}\right] \\
\text { and 5/days }\end{array}$ & $J_{\mathrm{SC}} / \mathrm{mA} \mathrm{cm}^{-2}$ & $V_{\mathrm{OC}} / \mathrm{mV}$ & $\mathrm{ff} / \%$ & $\eta / \%$ \\
\hline \multicolumn{6}{|c|}{ On the day of sealing the cell } \\
\hline$[\mathrm{Cu}(\mathbf{1})(5)]^{+}$ & 1 & 5.53 & 530 & 71.3 & 2.09 \\
\hline$[\mathrm{Cu}(\mathbf{1})(5)]^{+}$ & 3 & 7.01 & 559 & 70.2 & 2.75 \\
\hline N719 & & 15.93 & 647 & 71.7 & 7.39 \\
\hline \multicolumn{6}{|c|}{3 days after sealing the cell } \\
\hline$[\mathrm{Cu}(\mathbf{1})(\mathbf{5})]^{+}$ & 1 & 5.71 & 583 & 71.1 & 2.37 \\
\hline$[\mathrm{Cu}(\mathbf{1})(5)]^{+}$ & 3 & 6.93 & 588 & 67.6 & 2.75 \\
\hline N719 & & 15.40 & 677 & 71.0 & 7.40 \\
\hline \multicolumn{6}{|c|}{7 days after sealing the cell } \\
\hline$[\mathrm{Cu}(\mathbf{1})(5)]^{+}$ & 1 & 5.75 & 578 & 71.1 & 2.36 \\
\hline$[\mathrm{Cu}(\mathbf{1})(5)]^{+}$ & 3 & 6.96 & 587 & 66.3 & 2.71 \\
\hline N719 & & 15.18 & 685 & 69.4 & 7.22 \\
\hline
\end{tabular}


higher and lower energies in the EQE spectrum for the 3 day soaking time corresponds to the enhanced $J_{\mathrm{SC}}$ for the DSC prepared under these conditions. A control experiment was also carried out; a photoanode functionalized with anchoring ligand 1 was immersed in a $\mathrm{CH}_{2} \mathrm{Cl}_{2}$ solution of $\left[\mathrm{Cu}(\mathrm{MeCN})_{4}\right]\left[\mathrm{PF}_{6}\right]$ in the absence of ligand $\mathbf{5}$ for a day. After drying, the electrode appeared pale yellow in colour and the EQE spectrum of the DSC made with this electrode and $\mathrm{I}_{3}{ }^{-} / \mathrm{I}^{-}$electrolyte gave a maximum of only $4.36 \%\left(\lambda_{\max }=460 \mathrm{~nm}\right.$, Fig. 3$)$ in sharp contrast to the value of $47.8 \%\left(\lambda_{\max }=480 \mathrm{~nm}\right)$ obtained using a mixture of $\left[\mathrm{Cu}(\mathrm{MeCN})_{4}\right]\left[\mathrm{PF}_{6}\right]$ and 5 (eqn (2)) under the same assembly conditions.

To quantify the dye loading after different dye bath times, electrodes without a scattering layer were prepared by

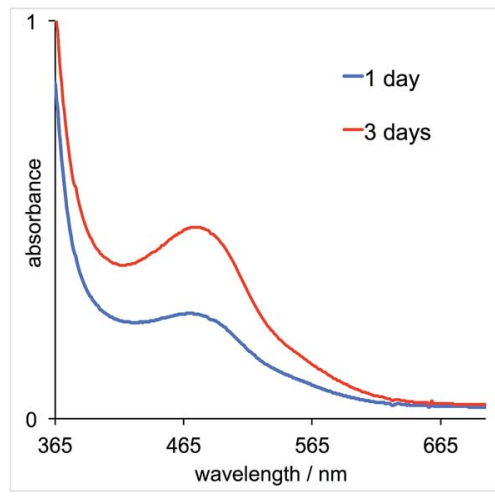

(a)

Fig. 4 (a) Solid-state absorption spectra and (b) photographs of electrodes prepared by immersing $\mathrm{TiO}_{2} / \mathrm{FTO}$ glass slides (no scattering layer) functionalized with 1 in $\mathrm{a} \mathrm{CH}_{2} \mathrm{Cl}_{2}$ solution containing $\left[\mathrm{Cu}(\mathrm{MeCN})_{4}\right]^{+}$and $5(1: 1)$ with dipping times of 1 or 3 days. immersing $\mathrm{TiO}_{2} /$ FTO glass slides functionalized with anchor 1 in a $\mathrm{CH}_{2} \mathrm{Cl}_{2}$ solution containing a $1: 1$ mixture of $\left[\mathrm{Cu}(\mathrm{MeCN})_{4}\right]^{+}$ and 5. After dipping times of 1 or 3 days, the solid-state absorption spectra of the electrodes were recorded and each spectrum was corrected for the background spectrum of a blank $\mathrm{TiO}_{2} /$ FTO electrode. The difference in absorption is significant (Fig. 4a) and is also seen by eye (Fig. 4b). In subsequent experiments with the co-adsorbant cheno, a period of 3 days was used for the dye dipping-cycle.

\section{Co-adsorbant cheno with the dye $[\mathrm{Cu}(1)(5)]^{+}$}

The effect of cheno on cell performance was investigated in two ways. In the first set of experiments, $\left[\mathrm{Cu}(\mathrm{MeCN})_{4}\right]\left[\mathrm{PF}_{6}\right]$ and ancillary ligand $\mathbf{5}$ were combined with cheno in the dye bath. In the second set of experiments (discussed later), cheno was loaded with anchoring ligand $\mathbf{1}$ in the first dipping-cycle. In the first series of DSCs, the dye was assembled according to eqn (2) but with cheno added to the mixture of $\left[\mathrm{Cu}(\mathrm{MeCN})_{4}\right]\left[\mathrm{PF}_{6}\right]$ and 5 in the dye bath. All components of the bath were used in concentrations of 0.1 $\mathrm{mM}$ and were in molar ratios of $\left[\mathrm{Cu}(\mathrm{MeCN})_{4}\right]\left[\mathrm{PF}_{6}\right]: 5$ : cheno of $1: 1: 1,1: 1: 3,1: 1: 6$ and $1: 1: 10$. Measurements of the DSC parameters were made on the day of cell fabrication, and after 3 and 7 days. A reference cell incorporating the dye N719 was also prepared, and Table 3 summarizes the performance data. The $J-V$ curves for the DSCs are shown in Fig. 5 and are compared with that for a DSC in which no coadsorbant was present (red curve in Fig. 5); this corresponds to the DSC in Table 2 with 3 days in the dye bath. Within experimental error (see Table $\mathrm{S} 2 \dagger$ for data with duplicate cells), the addition of cheno makes no significant difference to the overall DSC performance. The PCE of $2.71 \%$ without

Table 3 Performance data of masked DSCs with $[\mathrm{Cu}(1)(5)]^{+}$, cheno being introduced with ancillary ligand 5 and $\left[\mathrm{Cu}(\mathrm{MeCN})_{4}\right]^{+}$; data are compared to a DSC containing N719 and measured under the same conditions

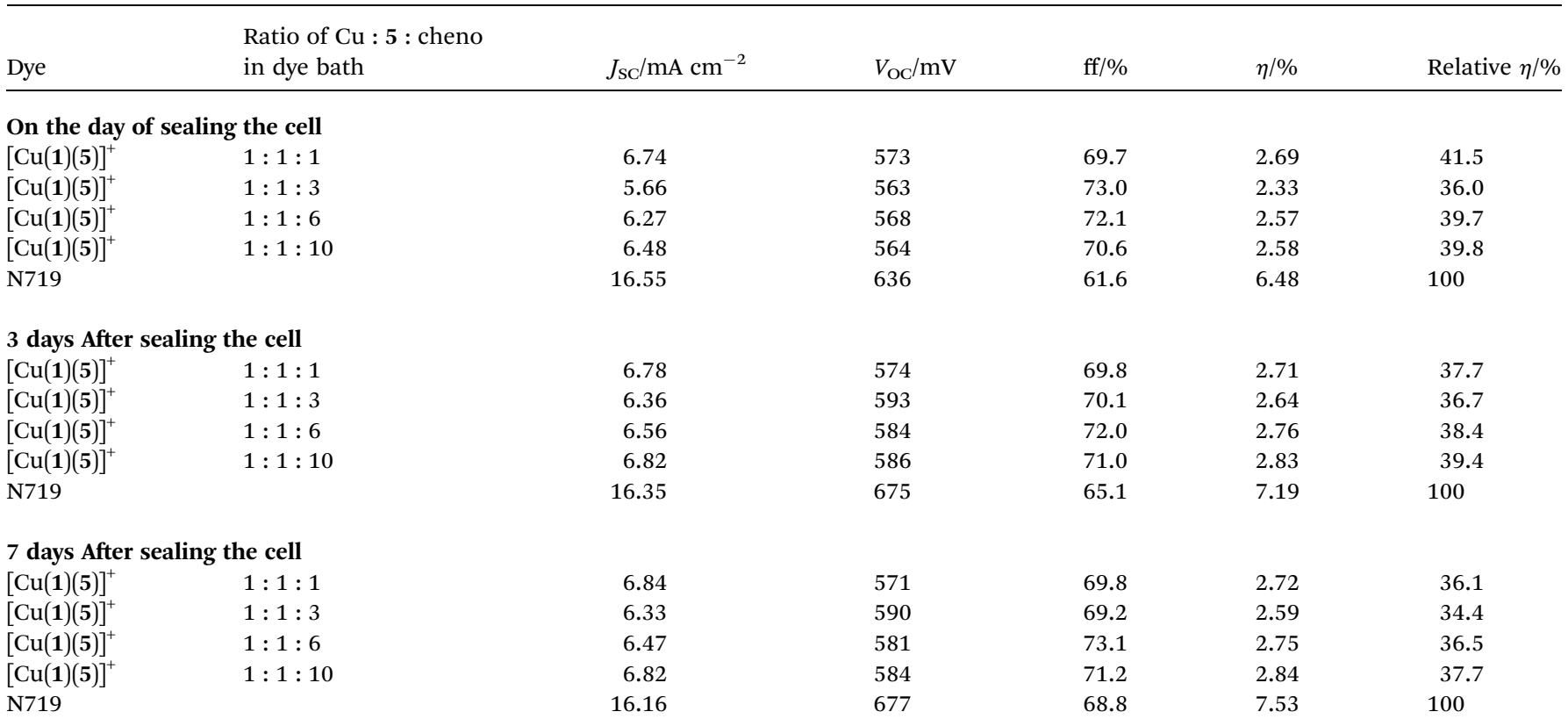




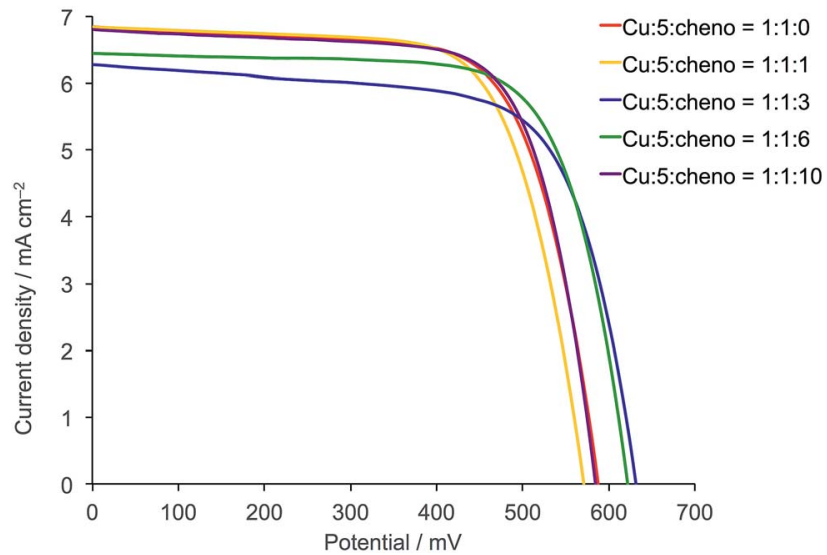

Fig. $5 \mathrm{~J}-V$ curves for 7 day old DSCs (see Table 3 ) in which the dye was assembled by dipping the electrode functionalized with 1 into a dye bath containing $\left[\mathrm{Cu}(\mathrm{MeCN})_{4}\right]\left[\mathrm{PF}_{6}\right], 5$ and cheno. The red curve corresponds to a DSC without cheno.

cheno (Table 2) compares to a range of $2.59-2.84 \%$ when cheno is added. All the DSCs exhibit good fill-factors of around $70 \%$.

The failure of cheno to enhance the performance of the $[\mathrm{Cu}(\mathbf{1})(5)]^{+}$sensitizer can be understood in terms of the dye possessing little steric crowding, and suggests that near-optimal dye coverage is obtained immediately the cells are assembled. When using the ligand exchange protocol (eqn (1)), we observed ripening effects, ${ }^{2}$ but these are not as dramatic as with more sterically encumbered ancillary ligands, ${ }^{\mathbf{1 6}}$ nor do we see significant time-dependent performance using the stepwise assembly of $[\mathrm{Cu}(\mathbf{1})(5)]^{+}$(eqn (2)). We were therefore interested to see the effects of introducing the co-adsorbant with the anchoring ligand (specifically whether there is competitive binding), prior to complexation with copper(I) and ancillary ligand. The dyefunctionalized photoanodes for the DSCs were prepared by immersing the electrode for a day in a DMSO solution containing 1 and cheno in molar ratios of $1: 1,1: 3$ and $1: 6$; stock solutions of each component were $0.1 \mathrm{mM}$. After drying, the electrode was then soaked for 3 days in a $\mathrm{CH}_{2} \mathrm{Cl}_{2}$ solution containing $\left[\mathrm{Cu}(\mathrm{MeCN})_{4}\right]\left[\mathrm{PF}_{6}\right]$ and ligand 5 in a $1: 1$ molar ratio. A reference electrode with N719 was also prepared. Performance parameters for the DSCs containing these photoanodes are shown in Table 4. Measurements were made at intervals up to a week after cell fabrication, and $J-V$ curves corresponding to 7 day old cells are depicted in Fig. 6.

Measurements made with a duplicate set of DSCs confirmed that the general trends in Table 4 and Fig. 6 were reproducible (Table S3 $\dagger$ ). The results indicate that adding cheno to the anchoring ligand during the first stage of dye assembly is detrimental. The open-circuit voltage achieved after 7 days without cheno (578 m, Table 2) is higher than the $V_{\mathrm{OC}}$ values observed with cheno (547 to $574 \mathrm{mV}$ ), and values of the shortcurrent current density are significantly lowered when cheno is added (from $6.96 \mathrm{~mA} \mathrm{~cm}^{-2}$ in the absence of cheno to $6.15 \mathrm{~mA}$ $\mathrm{cm}^{-2}$ and $5.75 \mathrm{~mA} \mathrm{~cm}^{-2}$ with $1: 1$ and $1: 6$ ratios of 1 : cheno). The consequence of the lower $J_{\mathrm{SC}}$ values (Fig. 6) is a drop in the cell PCE from $2.71 \%$ (no cheno, Table 2$)$ to $2.49 \%$ (1 : cheno $=$ $1: 1)$ to $2.27 \%(1:$ cheno $=1: 6)$. The EQE spectra of 7 day old DSCs are shown in Fig. 7. Although there is no unambiguous trend in the shape of the spectra with the amount of cheno added, it is apparent that the highest amount of cheno results in a loss of quantum efficiency at both lower and higher wavelengths.

Although both experiment and theory show that phosphonic acid anchors bind more strongly to $\mathrm{TiO}_{2}$ than carboxylic acid domains, ${ }^{34}$ our results are consistent with competitive binding of the bis(phosphonic acid) 1 with cheno ( $\mathrm{CO}_{2} \mathrm{H}$ anchor) which ultimately leads to a poorer surface coverage of the copper(I) dye.

Table 4 Performance data of masked DSCs with $[\mathrm{Cu}(1)(5)]^{+}$, cheno being introduced with anchoring ligand 1; data are compared to a DSC containing N719 and measured under the same conditions

\begin{tabular}{|c|c|c|c|c|c|c|}
\hline Dye & Ratio of 1 : cheno & $\begin{array}{l}J_{\mathrm{sc}} / \\
\mathrm{mA} \mathrm{cm}{ }^{-2}\end{array}$ & $\begin{array}{l}V_{\mathrm{OC}} / \\
\mathrm{mV}\end{array}$ & $\begin{array}{l}\mathrm{ff} / \\
\%\end{array}$ & $\begin{array}{l}\eta / \\
\%\end{array}$ & $\begin{array}{l}\text { Relative } \\
\eta / \%\end{array}$ \\
\hline \multicolumn{7}{|c|}{ On the day of sealing the cell } \\
\hline$[\mathrm{Cu}(\mathbf{1})(5)]^{+}$ & $1: 1$ & 5.43 & 566 & 68.9 & 2.12 & 28.0 \\
\hline$[\mathrm{Cu}(\mathbf{1})(\mathbf{5})]^{+}$ & $1: 3$ & 5.92 & 558 & 67.7 & 2.23 & 29.4 \\
\hline$[\mathrm{Cu}(\mathbf{1})(\mathbf{5})]^{+}$ & $1: 6$ & 5.73 & 536 & 68.8 & 2.11 & 27.8 \\
\hline N719 & & 16.18 & 656 & 71.4 & 7.58 & 100 \\
\hline \multicolumn{7}{|c|}{3 days after sealing the cell } \\
\hline$[\mathrm{Cu}(\mathbf{1})(\mathbf{5})]^{+}$ & $1: 1$ & 6.02 & 570 & 70.0 & 2.40 & 31.6 \\
\hline$[\mathrm{Cu}(\mathbf{1})(\mathbf{5})]^{+}$ & $1: 3$ & 6.45 & 538 & 69.1 & 2.39 & 31.4 \\
\hline$[\mathrm{Cu}(\mathbf{1})(\mathbf{5})]^{+}$ & $1: 6$ & 5.79 & 562 & 70.1 & 2.28 & 30.0 \\
\hline N719 & & 16.18 & 671 & 70.0 & 7.60 & 100 \\
\hline \multicolumn{7}{|c|}{7 days after sealing the cell } \\
\hline$[\mathrm{Cu}(\mathbf{1})(\mathbf{5})]^{+}$ & $1: 1$ & 6.15 & 574 & 70.7 & 2.49 & 31.5 \\
\hline$[\mathrm{Cu}(\mathbf{1})(\mathbf{5})]^{+}$ & $1: 3$ & 6.59 & 547 & 70.0 & 2.52 & 31.9 \\
\hline$[\mathrm{Cu}(\mathbf{1})(\mathbf{5})]^{+}$ & $1: 6$ & 5.75 & 564 & 70.0 & 2.27 & 28.7 \\
\hline N719 & & 16.14 & 697 & 70.4 & 7.91 & 100 \\
\hline
\end{tabular}

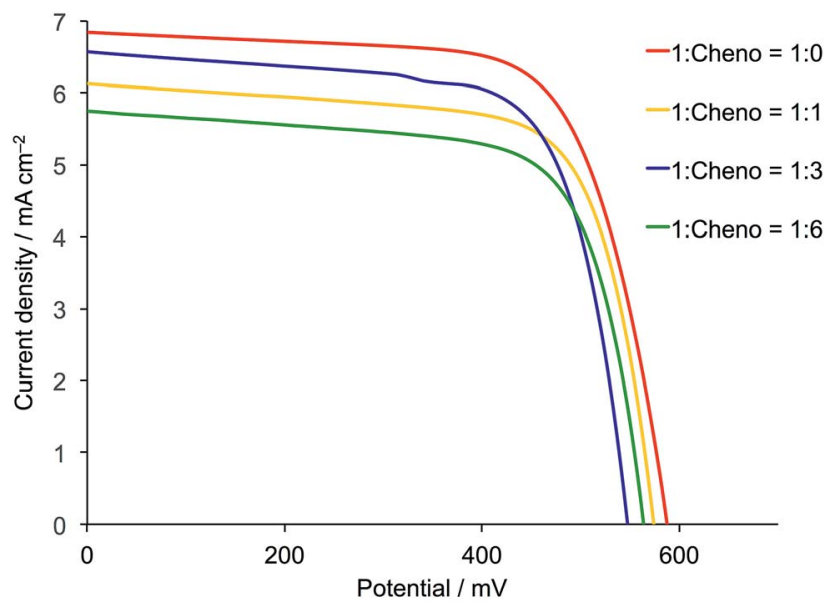

Fig. 6 J-V curves for 7 day old DSCs (see Table 4) in which the dye was assembled by dipping the electrode into a DMSO solution of 1 and cheno (different ratios), followed by treatment with $\left[\mathrm{Cu}(\mathrm{MeCN})_{4}\right]\left[\mathrm{PF}_{6}\right]$ and 5 . The red curve corresponds to a DSC without cheno. 


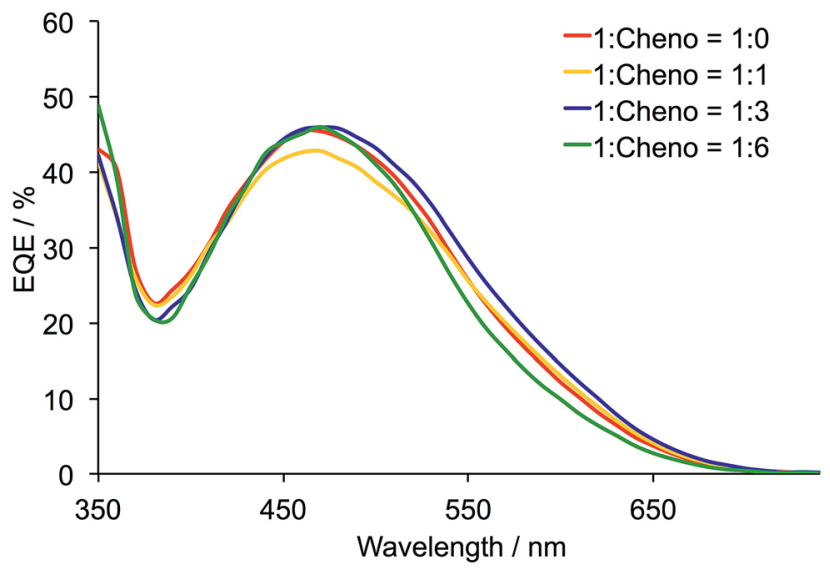

Fig. 7 EQE spectra for 7 day old DSCs in which the dye was assembled by dipping the electrode into a DMSO solution of 1 and cheno (different ratios), followed by treatment with $\left[\mathrm{Cu}\left(\mathrm{MeCN}_{4}\right]\left[\mathrm{PF}_{6}\right]\right.$ and 5 . The red curve corresponds to a DSC without cheno.

\section{Conclusions}

The copper(I) dyes $[\mathrm{Cu}(\mathbf{1})(\mathbf{3})]^{+}$and $[\mathrm{Cu}(\mathbf{1})(\mathbf{4})]^{+}$contain sterically demanding second-generation hole-transporting dendrons with methyl or phenyl substituents in the 6- and 6'-positions of the bpy metal-binding domain in ligands 3 and 4 . The performance of DSCs containing these dyes depends on both the solvent (acetone or $\mathrm{CH}_{2} \mathrm{Cl}_{2}$ ) in the dye-bath and the use of a coadsorbant. Addition of cheno improves the performance of dyes $[\mathrm{Cu}(\mathbf{1})(\mathbf{3})]^{+}$and $[\mathrm{Cu}(\mathbf{1})(\mathbf{4})]^{+}$originating from the $\mathrm{CH}_{2} \mathrm{Cl}_{2}$ solutions in the dipping cycles. The performance of $[\mathrm{Cu}(\mathbf{1})(\mathbf{4})]^{+}$with the most sterically demanding ancillary ligand is considerably improved when cheno is added $(\eta=0.50-1.24 \%$, or $6.8-15.5 \%$ relative to N719 normalized to $100 \%)$. A similar enhancement is seen for the acetone-derived $[\mathrm{Cu}(\mathbf{1})(\mathbf{4})]^{+}(1.29-2.45 \%$ without and with cheno, respectively), but a lesser effect is observed for acetone-derived $[\mathrm{Cu}(\mathbf{1})(\mathbf{3})]^{+}$.

The dye $[\mathrm{Cu}(\mathbf{1})(5)]^{+}$was assembled in a stepwise manner on nanoparticulate $\mathrm{TiO}_{2}$ (eqn (2)) and the conditions for this procedure have been optimized. We have investigated the effects of introducing cheno in either the $\left[\mathrm{Cu}(\mathrm{MeCN})_{4}\right]\left[\mathrm{PF}_{6}\right] / 5$ or anchoring ligand 1 dipping-cycles. When cheno is added to the $\left[\mathrm{Cu}(\mathrm{MeCN})_{4}\right]\left[\mathrm{PF}_{6}\right] / 5$ dye-bath, the DSCs exhibit parameters $\left(U_{\mathrm{sC}}\right.$, $V_{\mathrm{OC}}$ and $\eta$ ) which are similar to those for cells without coadsorbant. In contrast, the addition of cheno to 1 in the first dipping-cycle has an unfavourable effect, resulting in lower values of $J_{\mathrm{sc}}$ and overall efficiencies, $\eta$. This is attributed to competitive binding of $\mathbf{1}$ and cheno leading to a dye loading which is less than optimal.

\section{Acknowledgements}

The European Research Council (Advanced Grant 267816 LiLo), Swiss National Science Foundation and University of Basel are acknowledged for financial support. We particularly thank Dr Biljana Bozic-Weber for useful discussions.

\section{Notes and references}

1 B. Bozic-Weber, E. C. Constable and C. E. Housecroft, Coord. Chem. Rev., 2013, 257, 3089.

2 F. J. Malzner, S. Y. Brauchli, E. C. Constable, C. E. Housecroft and M. Neuburger, RSC Adv., 2014, 4, 48712.

3 M. Sandroni, L. Favereau, A. Planchat, H. Akdas-Kilig, N. Szuwarski, Y. Pellegrin, E. Blart, H. Le Bozec, M. Boujtita and F. Odobel, J. Mater. Chem. A, 2014, 2, 9944.

4 N. Alonso-Vante, J.-F. Nierengarten and J.-P. Sauvage, J. Chem. Soc., Dalton Trans., 1994, 1649.

5 S. Sakaki, T. Kuroki and T. Hamada, J. Chem. Soc., Dalton Trans., 2002, 840.

6 T. Bessho, E. C. Constable, M. Grätzel, A. Hernandez Redondo, C. E. Housecroft, W. Kylberg, M. K. Nazeeruddin, M. Neuburger and S. Schaffner, Chem. Commun., 2008, 3717.

7 E. C. Constable, A. Hernandez Redondo, C. E. Housecroft, M. Neuburger and S. Schaffner, Dalton Trans., 2009, 6634.

8 B. Bozic-Weber, E. C. Constable, C. E. Housecroft, M. Neuburger and J. R. Price, Dalton Trans., 2010, 39, 3585.

9 Y.-J. Yuan, Z.-T. Yu, J.-Y. Zhang and Z.-G. Zou, Dalton Trans., 2012, 41, 9594.

10 B. Bozic-Weber, S. Y. Brauchli, E. C. Constable, S. O. Fürer, C. E. Housecroft, F. J. Malzner, I. A. Wright and J. A. Zampese, Dalton Trans., 2013, 42, 12293.

11 B. Bozic-Weber, E. C. Constable, C. E. Housecroft, P. Kopecky, M. Neuburger and J. A. Zampese, Dalton Trans., 2011, 40, 12584.

12 B. Bozic-Weber, V. Chaurin, E. C. Constable, C. E. Housecroft, M. Meuwly, M. Neuburger, J. A. Rudd, E. Schönhofer and L. Siegfried, Dalton Trans., 2012, 41, 14157.

13 B. Bozic-Weber, S. Brauchli, E. C. Constable, S. O. Fürer, C. E. Housecroft and I. A. Wright, Phys. Chem. Chem. Phys, 2013, 15, 4500.

14 T. E. Hewat, L. J. Yellowlees and N. Robertson, Dalton Trans., 2014, 43, 4127.

15 B. Bozic-Weber, E. C. Constable, S. O. Fürer, C. E. Housecroft, L. J. Troxler and J. A. Zampese, Chem. Commun., 2013, 49, 7222.

16 S. Y. Brauchli, B. Bozic-Weber, E. C. Constable, N. Hostettler, C. E. Housecroft and J. Zampese, RSC Adv., 2014, 4, 34801.

17 A. Hernandez Redondo, E. C. Constable and C. E. Housecroft, Chimia, 2009, 63, 205.

18 See for example: M. Schmittel and A. Ganz, Chem. Commun., 1997, 999; M. Schmittel, H. Ammon, V. Kalsani, A. Wiegrefe and C. Michel, Chem. Commun., 2002, 2566.

19 M. Sandroni, M. Kayanuma, A. Planchat, N. Szuwarski, E. Blart, Y. Pellegrin, C. Daniel, M. Boujtita and F. Odobel, Dalton Trans., 2013, 42, 10818.

20 N. R. Neale, N. Kopidakis, J. van de Lagemaat, M. Grätzel and A. J. Frank, J. Phys. Chem. B, 2005, 109, 23183.

21 Q. Wang, W. M. Campbell, E. E. Bonfantani, K. W. Jolley, D. L. Officer, P. J. Walsh, K. Gordon, R. Humphry-Baker, M. K. Nazeeruddin and M. Grätzel, J. Phys. Chem. B, 2005, 109, 15397. 
22 C.-W. Lee, H.-P. Lu, C.-M. Lan, Y.-L. Huang, Y.-R. Liang, W.-N. Yen, Y.-C. Liu, Y.-S. Lin, E. W.-G. Diau and C.-Y. Yeh, Chem.-Eur. J., 2009, 115, 1403.

23 C. L. Linfoot, P. Richardson, T. E. Hewat, P. Moudam, M. M. Forde, A. Collins, F. White and N. Robertson, Dalton Trans., 2010, 39, 8945.

24 B. Wenger, M. Grätzel and J.-E. Moser, J. Am. Chem. Soc., 2005, 127, 12150.

25 B. Wenger, M. Grätzel and J.-E. Moser, Chimia, 2005, 59, 123.

26 V. K. Thorsmølle, B. Wenger, J. Teuscher, C. Bauer and J.-E. Moser, Chimia, 2007, 61, 631.

27 F. J. Malzner, S. Y. Brauchli, E. Schönhofer, E. C. Constable and C. E. Housecroft, Polyhedron, 2014, 82, 116.

28 S. Y. Brauchli, E. C. Constable and C. E. Housecroft, Dyes Pigm., 2015, 113, 447.
29 G. J. Kubas, Inorg. Synth., 1990, 28, 68.

30 S. Ito, P. Chen, P. Comte, M. K. Nazeeruddin, P. Liska, P. Péchy and M. Grätzel, Prog. photovoltaics, 2007, 15, 603.

31 S. Ito, T. N. Murakami, P. Comte, P. Liska, C. Grätzel, M. K. Nazeeruddin and M. Grätzel, Thin Solid Films, 2008, 516, 4613.

32 H. J. Snaith, Energy Environ. Sci., 2012, 5, 6513.

33 X. Chen, C. Jia, Z. Wan, J. Feng and X. Yao, Org. Electron., 2014, 15, 2240.

34 See for example: M. Nilsing, P. Persson and L. Ojamäe, Chem. Phys. Lett., 2005, 415, 375; S. Pawsey, K. Yach and L. Reven, Langmuir, 2002, 18, 5205; R. Luschtinetz, S. Gemming and G. Seifert, Eur. Phys. J. Plus, 2011, 126, 98; C. O'Rourke and D. R. Bowler, J. Phys.: Condens. Matter, 2014, 26, 195302. 